\title{
Киевский ордена Ленина политехнический институт
}

\section{(радиотехнический факультет)}

ТрохименкоЯ. К., Обратная связ в в усилителях на кристаллических триодах. Научный руководитель чл.-Корр. АН УССР д. т. н. проф. С. И. Тетельбаум. Защита состоялась 18 февраля 1957 г. Официальные оппоненты: д. т. н. проф. Н. Ф. Воллернер, к. т. н. Б. Н. Малиновский.

Обобщается и развивается теория обратной связи в схемах с полупроводниковыми трнодами. Рассматриваются вопросы, связанные с применением матрнцного аппарата для анализа схем с полупроводниковыми триодами. Выводятся расчетиые соотношения для усилителей, охваченных обратной связыо и анализируется стабилизирующее действие последней как на частоте сигнала, так и на постоянном токе. Частотные свойства плоскостного триода описываются при помощи эквивалентных проводимостей П-образной схемы замещения.

Анализируются услсвия устойчнвости усилительюого каскада.

Гордиенко А. Г. Исследование влияния импульсов на разборчивость русских речевых сообщен и й. Научный руководитель д. т. н. проф. Н. Ф. Воллернер. Защита состоялась 15 апреля 1957 г. Официальные оппоненты: д.т.н. проф. М. И. Карновский, к. т. н. А. В. Шереметьев.

Исследуется помехоустойчивость русских речевых сообщений при импульсных помехах и влияние относлтельной интенсивности последних на разборчнвость.

Определяется зависимость артикуляции от частоты следования импульсов (как регулярных, так и нерегулярных во времени).

Результаты исследования показывают, что естественные русские сообщения обладают значительным избытком полезных сведений.

Яковлев В. Н. Исследование элементовим пльсных устройств на полупроводниковых триодах. 3 ащита состоялась 10 июня 1957 г. Официальные оппоненты: д. т. н. проф. Н. Ф. Воллернер, к. т. н. Б. Н. Малиновский.

Излагается методнка графоаналитического расчета схем мультивибраторов на точечных полупроводниксвых триодах с эмиттерной, эмиттерно-коллекторной и коллекторной емкостью и индуктивностью в цепи базы, а также схем блокинг-генератора на плоскостном полупроводниковом трнсде. Исследуется применение линий задержки для стабилизации длительности импульса. Предлагается графоаналитический метод анализа переходных процессов в мультивнбраторе на точечном трноде с эмиттернсй емкостью.

Круковский-Синевич К. Б. Анализ помехоустой. чивости радиоприемных устрой ств с коммутируем ы м и фи льт р а м и. Научный руководитель д. т. н. проф. Н. Ф. Вол. лернер. Защита состоялась 24 июня 1957 г. Официальные оппоненты: д. т. н. проф. М. И. Қарновский, к. т. н. В. И. Сошников.

Исследуется помехоустойчивость импульсных радиоприемных устрєйств с коммутируемыми фнльтрами при воздействни гладких и импульсных помех. Рассматрнваются коммутируемые фнльтры четырех типов: одноконтурные и полосовые фнльтрь: 
включенные до детектора, и $R C$-фильтры нижних частот и полосовой фильтр нижних частот, включенные после детектора.

Показано, что применение коммутируемых фильтров в радиотелеграфии улучшает отношение сигнал/помеха при воздействии гладких и импульсных помех.

Мигулин И. Н. Вопросы теории и расчета усилителе й на полупроводн нковых тр нодах. Защита состоялась 28 октября 1957 г. Официальные оппоненты: д. т. н. проф. Н. Ф. Воллернер, к. т. н. В. И. Ущанкнн.

В диссертации на основе использования П-образной схемы замещения для рабочего диапазона частот и эквивалентных проводимостей плоскостного полупроводникового триода выводятся расчетные формулы, аналогичные соответствующим формулам для ламповых усилителей. Рассматривается возможность использсвания при расчете усредненных параметров трнода. Показано, что основные параметры триода являются линейными функциями тока коллектора. Теоретически и экспериментально исследуется ряд схем усилителей, в частности, резонансных и широкополосных. Рассматривается связь конструктивных параметров плоскостного триода с џх усилительными свойствами.

Плотников В. Н. Широкопо.лосная частотная модуляция, основанная на подмагничивании ферритовых сердечников. Научный руководитель д. т. н. проф. Н. Ф. Воллернер. Защита состоялась 9 декабря 1957 г. Официальные оппоненты: д. т. н. проф. В. А. Дьяков, к. т. н. доц. М. М. Некрасов.

Исследуется зависимость обратной проницаемости ферритов от напряженности подмагничивающего поля. На основании экспериментальных данных рассматривается возможность применения ферритов в широкополосных частотных модуляторах. Анализируются искажения и паразитная амплитудная модуляция в модуляторах с электромагнитом и непосредственным подмагничнванием ферритового сердечника. Рассматриваются способы устранення паразитной амплитудной модуляции.

Проф. В. В. Огиевский. 